\title{
EARTHQUAKES AND TALL BUILDINGS+
}

\author{
Paul C. Jennings*
}

\begin{abstract}
Editor's Note: Professor Jennings" contribution is, he says, "relatively non-technical, and is aimed primarily at laymen and engineers not directly engaged in structural engineering". Papers of this sort are so rare that we are delighted to offer this one from so respected an authority as Professor Jennings, not only for those of our members that the Professor intended should benefit, but also for structural engineers. All of us, deeply involved with technical detail, tend to lose something of our appreciation of the overall problem.
\end{abstract}

\section{Introduction}

There seems little doubt that the response of tall buildings to strong earthquake motion occupies a special place in the public mind. In April of last year in Los Angeles, when popular attention was focused again on the earthquake problem by the dire predictions of a variety of soothsayers, the two questions that invariably arose in conversation were "Will there really be an earthquake in April?" and "What about the tall buildings in downtown Los Angeles?" April passed without a large shock, so the first question has been resolved. A big earthquake will almost certainly occur in southern California some day, however, and the second question remains valid. Similar questions arise here in New Zealand and wherever tall buildings are built in seismic areas.

This concern with tall buildings is not new; the same question regarding their performance in earthquakes was asked in San Francisco in 1897 when the Call Building (15 stories plus dome) was erected on Market street, and there was difficulty renting space in the 43storey Tower Latino Americano in Mexico City prior to the earthquake of 1957. In both these cases the excellent earthquake performance of the buildings earned the confidence of the public. As will be seen in what follows, there are reasons to believe that this will also be the case in the next big earthquake in southern California.

What comprises a tall building is relative to the times, but tall buildings in the over 30-storey class are relatively recent features in seismic regions of the world. With the exception of City Hall, such buildings did not appear in Los Angeles until the $1960^{\prime} \mathrm{s}$, and this same period witnessed a dramatic increase in the numbers of tall buildings in

+ Adapted from public lectures at the California Institute of Technology and the University of Canterbury.

* Associate Professor of Applied Mechanics, California Institute of Technology and Visiting Erskine Fellow, University of Canterbury, Christchurch, Feb - May, 1970.
San Francisco and the Pacific Northwest. Buildings over about 6 stories did not appear in Tokyo until the construction of the 36storey Kasumigaseki Building in 1966. The Tower Latino Americano introduced tall buildings to Mexico City in 1957 and a 40-storey building is under construction in Lima, Peru. The few buildings in Caracas in the 30-storey range also are recent additions. There are no buildings of this size yet in chile or in New Zealand, and the tallest buildings in Anchorage at the time of the Alaska earthquake of 1964, and now, are fourteen stories. The trend towards tall buildings is so strong, however, that it seems likely that every major city in the pacific area will soon have buildings over thirty stories.

\section{Properties of Tall Buildings}

It is important to realize that buildings, especially tall buildings, are not rigid, but are flexible systems with well-defined dynamic properties. These dynamic properties, including the natural frequencies, mode shapes and energy dissipation ability or damping, are what determine the earthquake response of the structure. For example, one very important characteristic is the fundamental period of vibration. This period is predicted with reasonable accuracy for many tall buildings simply by dividing the number of stories by ten. Thus, a 40-storey building would be expected to have a fundamental period somewhere near four seconds.

Other dynamic properties are not found or estimated so easily, and one of the continuing research efforts in earthquake engineering is to measure the dynamic properties of buildings and other structures, both to improve the techniques by which such properties are calculated and to interpret the subsequent earthquake performance of the structure. The writer's most recent effort along these lines was a vibration experiment, conducted jointly with the University of California, Los Angeles, in which the dynamic properties of the new 21 storey San Diego Gas and Electric Company Building in downtown San Diego were measured. Some of the lower, translational natural periods and mode shapes of this steel- 
frame structure are shown in Figure 1.

Tall buildings share many similar properties and it is quickly observed that they differ from short buildings in more ways than just in height. The tall buildings have more regular geometry and are nearly all symmetrical. usually being rectangular. This results from economic and architectural considerations. The constant cross-sectional area of the buildings leads to a weight distribution that is approximately uniform with height. In addition, code requirements usually dictate that all the tall buildings have a moment resisting frame rather than, or in addition to, the shear walls that are often used in shorter buildings. As would be expected, the weight distribution and the type of structural system are reflected in the dynamic properties of the building.

Both steel frame and reinforced concrete frame construction have been used for high-rise buildings and most engineers agree that earthquake-resistant structures can be made from both of these construction materials. Statistically speaking, however, nearly all of the buildings in the 30-storey and up class are steel-frame structures. The dynamic properties of both types are similar, but for structures of the same height, the reinforced concrete buildings are usually stiffer than buildings framed of steel.

Because the tall buildings are more flexible than the shorter buildings, they are sensitive to a different frequency range in the earthquake excitation. This frequency sensitivity affects their earthquake response as indicated in Figure 2. In a simplified view, earthquake waves of various periods originating from the fault travel through the earth with the same velocity, with the amplitude of each succeeding oscillation being a fraction, nearly unity, of the preceding oscillation. Because the longer period waves travel further in each cycle, their amplitudes remain relatively large for greater distances and are significant to structures over a wider area than are the short period, high frequency waves which excite the smaller buildings. For this reason, it is typical that tall buildings sway in distant earthquakes while short buildings are relatively unaffected. In continuing reference to Figure 2, if this same earthquake were to occur close by, the short buildings would receive much more shaking, whereas the swaying of the tall buildings would be larger but not much larger than in the more distant shock. The occupants of the taller buildings would feel both swaying and some significant shaking from the closer shock, because the same range of frequencies that excite the small buildings would cause the higher modes of the taller buildings to vibrate.

\section{Earthquake Effects_on Tall Buildings}

There is a limited amount of experience with tall buildings in strong earthquakes, but the experience available is encouraging. The 43storey Tower Latino Americano survived the
Mexican earthquake of July 1957, with insignificant damage even though several shorter buildings collapsed. The earthquake occurred after the structural frame was complete, but before the glass was completely installed. None of the installed panes of glass was broken. In the Caracas, Venezuela earthquake of July 1967, the buildings in the 30-storey range all came through the earthquake with no significant damage, whereas five buildings of intermediate height collapsed with major loss of life.

\section{Longer ago, the Call Building in San} Francisco withstood the Magnitude 8.2 earthquake of 1906 with almost no damage, as did other tall buildings and building frames. Figure 3 shows the Call Building and Market Street after the earthquake and during the fire. The building appears to be completely undamaged by the vibration. The damage in the right foreground of Figure 3 is thought to be from dynamiting, a technique used to try to control the spread of the fires.

\section{Effects of Height on Earthquake Response}

Because really strong earthquake motions are so rare at any given site, it does not make sense to design all structures to withstand the strongest earthquake without damage. The currently accepted design philosophy for earthquake-resistant structures is that the structure be capable of withstanding, without damage, the small to moderate earthquakes that are likely to occur within the lifetime of the structure. Damage is permitted in the event of a very large earthquake which has only a small chance of occurring in the structure's lifetime, but the structure should not fail and should protect its occupants from serious injury. In terms of deflections, this means that the maximum response should not exceed 4 to 6 times the elastic limit of the frame. This philosophy of controlled damage is implicit in building codes, such as are operative in New Zealand and the U.S. These codes specify the forces to be resisted at stress levels below yield; but the forces are significantly less than actually expected during strong earthquakes.

For most of the tall buildings, an extra margin of safety against the strongest shaking is achieved by designing the structure so that the less critical horizontal members go into yielding before the columns. This feature, combined with the level of strength required to resist earthquakes, winds, and vertical loads, and needed to meet deflection criteria, combine to make the overall strength of the tall buildings higher, relatively speaking, than that of the typical small building.. Computer analyses indicate that the earthquake response of most of the tall building structures will be nearly elastic, even for very strong shaking. Therefore, studies of the linear response of tall buildings are applicable to the earthquake response of these structures. 
ing, - these are the properties needed to predict the earthquake response of tall buildings. Many more tests are needed, but when the data available are gathered together and examined some patterns do emerge as will be seen from examination of Table I. (1) It is found, for example, that the ratios of the higher frequencies to the fundamental tend to follow very nearly the odd integers; Table I shows the ratios for the second through the sixth North-South frequencies of the Union Bank Building to be 2.9, 5.09, 7.18, 9.25 and 11.5 . In this respect the building has properties mud like a simple beam that deforms only in shear. It is found also that the mode shapes of the tall buildings, particularly those associated with the higher frequencies, are quite similar. As an example, Figure 4 shows the second mode shapes of a number of tall buildings. (1) For comparison, Figure 5 shows the first three modes of a 15-storey building in one direction at different stages of construction, following the completion of the structural frame. (2) Although there are some other factors involved, comparison of Figures 4 and 5 does suggest that the differences in mode shapes of different buildings is not much larger than the errors involved in trying to find the actual mode shapes of a single building.

The similarities in frequencies and mode shapes appear to hold fairly true for all tall buildings, independent of height, plan dimension and construction material. As mentioned above, the fundamental periods tend to increase nearly linearly with height, with reinforced concrete buildings tending to be somewhat stiffer than steel-frame structures.

The similarity of measured properties shows that it is meaningful to speak of typical or average properties of tall buildings. Using such average properties and the average spectral properties of strong earthquake motions, (3) it is possible to study the earthquake response of tall buildings in a statistical sense, and in particular to examine the consequences of increasing height.

The results of such a study were reported at the Fourth World Conference on Earthquake Engineering in Santiago, Chile in January 1969. (1) In summary, it was concluded that the effects of height establish the following trends in the earthquake response of tall buildings:

(1) The average maximum deflection, at the top of the buildings, tends to increase linearly with height and is determined almost entirely by the fundamental mode of response.

(2) As the buildings get taller, the maximum base shear transmitted by the ground to the base of the structure tends, on the average, to become independent of height, approaching a constant value.

(3) The maximum value of the base moment exerted by the ground on the structure tends, on the average, to increase line- arly with height and is determined essentially by the fundamental mode.

(4) The maximum value of the acceleration on the top of tall buildings tends, on the average, to decrease approximately as the inverse square root of the height. For a very tall building, the motion on the top is expected to be less severe than at the base.

Computer calculations of the response of tall buildings to recorded earthquake motion tend to support these conclusions and it is interesting to note in this regard also that Professor Charles Derleth of the University of California at Berkeley reported in his study of the 1906 earthquake that "... the base of such a structure (relatively tall buildings) oscillated and moved with the earth whife the top tried to remain quiet. This statement is substantiated by the general evidence that less shock was felt in the upper stories of high buildings than in floor levels near the street." It is the view of the writer that this effect was somewhat fortuitous for buildings so short by present standards, but it is a good description of the type of phenomena that is expected to be more common as taller buildings are considered. This effect is illustrated by Figure 6 which shows, for several buildings, the ratio of the maximum acceleration at the top of the building to the maximum recorded at the base of the structure. A magnification of about three seems typical for buildings for intermediate height, and the calculated result $\mathrm{s}$ from the motion recorded in $\mathrm{El}$ centro in 1940 are in agreement with the trend noted above.

\section{Comparison with Wind Effects}

If the loading required to resist wind action is examined for purposes of comparison, the effects of increasing height are found to be quite different. The codes for wind specify the pressure on the sides of the buildings and the magnitude of the pressure increases with height. As a result, the net lateral force on the building tends to increase with height at a greater than linear rate, and the total moment of the loads tends to increase faster than the square of the building height.

Because the wind forces increase with height more rapidly than the earthquake forces, there is a height at which wind becomes a more serious design problem, in general, than earthquakes. The trade-off height varies according to whether code forces or actual forces are used to define the wind and earthquake loadings, but for the regulations currently in force in Los Angeles the code wind forces become more severe than the code earthquake forces somewhere near the 30-40 storey range. As an example of the relative effects, in the design of the 42-storey Crocker-Citizens Building the code wind forces gave a total lateral load more than twice the total load specified by the earthquake code. As a result, an additional margin of strength against earthquakes is achieved through the 
requirements of wind resistance.

\section{Design of Tall Buildings}

Because tall buildings are relatively new in seismic areas, the engineering profession has limited experience with their earthquake performance. Furthermore, the existing building codes, based in substantial part on earthquake experience with much smaller buildings, are not completely applicable to the design of tall structures. Responsible engineers are aware of this, of course, and give the design of tall buildings the special care that their importance deserves. The expanding knowledge about earthquakes, structures and calculation techniques, and the growing capabilities of the digital computer place the engineers in an increasingly better position to design tall buildings and other structures to withstand strong earthquakes successfully.

In the design of tall buildings, the structural engineers nearly always make more extensive analyses than required by the code. one technique of analysis that seems certain to become more common is the use of the digital computer to calculate the response of the proposed design to recorded earthquake motions and artificially generated motions that model the shaking expected in the event of a great earthquake. (The motion in the epicentral area of a magnitude 8 or greater earthquake has not yet been recorded).

The results of such analyses, the necessity of resisting the wind forces specified by codes, and the requirement to resist these forces within certain deflection limits have all combined to make the earthquake resistance of the tall buildings superior, on the average, to the shorter ones and substantially stronger than necessary just to meet code requirements. For example, calculations indicate that the 42-storey Union Bank Building in Los Angeles can withstand the strongest destructive ground motion yet recorded (El centro,. 1940, N-S component) with only a few noncritical members being stressed beyond their elastic limits. By comparison, similar calculations have indicated that typical California buildings in the 5-15 storey range would be shaken well into the yielding range by this earthquake, and some structural damage would be expected.

\section{Conclusions}

Some conclusions can be reached from study of the measured properties of tall buildings. the limited but successful earthquake experience with these structures and the results of analyses which bear on the subject. These conclusions will no doubt be modified, enlarged and joined by others as both our experience with the earthquake performance of tall buildings and our knowledge of their properties accumulates. Certainly there are still many unanswered questions remaining in this aspect of earthquake engineering.

$E_{a}$ rthquake experiences throughout the world have shown that well designed and con- structed buildings, including tall buildings, can withstand strong earthquake shaking without excessively endangering the occupants. on the other hand, earthquakes have demonstrated repeatedly that under-designed buildings, or poorly built buildings, of all heights are a definite hazard during strong earthquake motions. The earthquake success of tall buildings is reinforced by studies using average properties of earthquakes and typical properties of tall buildings. These studies show that the properties of tall buildings are such that there are no special earthquake hazards that arise simply as a consequence of height. In fact, for the very tall buildings the lateral forces required by the codes in Los Angeles are such that the wind forces exceed the code earthquake loadings by a substantial amount. This increases the margin of safety against earthquake motions to the extent that the amount of yielding in strong shaking is quite limited; much less than for most shorter structures. These reasons help the writer to conclude that carefully designed and constructed tall buildings can be built safely in seismic regions.

In a general sense, the earthquake resistance of most of the cities of the world is improving. The increase in understanding of the earthquake, motions, a better knowledge of the dynamic properties of buildings, and the increasing capacity to perform complex calculations on the digital computer are all combining with better building codes to make nearly all modern buildings, including tall buildings, much less of a hazard than the buildings of a few decades ago.

one facet of earthquake damage to buildings of all heights which has not received the attention it deserves is the damage to non-structural features. Partitions, filler walls, ceilings, light fixtures, elevator equipment, bookcases, storage racks and all types of electrical and mechanical machinery often have shown themselves susceptible to earthquake damage. These damages are often hazardous and nearly always expensive to repair. Damage to nonstructural elements is typically the greatest monetary loss in a building damaged by an earthquake, exceeding substantially the cost of any damage to the structural frame. This is true even if the building collapses because the structural frame usually represents only about $1 / 3$ the cost of the building.

The Hancock Building in Chicago and the Alcoa Building in San Francisco, with their exterior $\mathrm{X}$-bracing, seem to portend that we can expect a wider variety of structural framing systems to be used in tall buildings in the future. There is no inherent reason why different framing systems cannot be used in building structures in earthquake zones; each framing system and each building should be examined on its own merits.

Even though the general picture 
is improving, it would be a mistake to have too bright a picture of the effects of strong earthquakes. Strong earthquakes are a frightening and hazardous experience and are likely to remain so for many years to come. We should try, however, to put the various sources of hazard into proper perspective so we can focus our efforts on those that are most serious. For a variety of reasons, the very tall buildings appear to be in a relatively good position in this regard, especially when compared to the tens of thousands of old buildings built before earthquake-resistant design was first required. A sizeable fraction of these buildings are substandard and represent, in the writer's opinion, the greatest hazard during the next strong earthquake in the metropolitan areas of California or New Zealand. The next largest hazard probably comes from speculatively built buildings of intermediate height.

\section{REFERENCES}

1. Jennings, P.C., "Spectrum Techniques for Tall Buildings", Proceedings of the Fourth World Conference on Earthquake Engineering, Santiago, Chile, January, 1969.

2. Rea, D., Bouwkamp, J.G., and Clough, R.W., "The Dynamic Behaviour of Steel Frame and Truss Buildings", Structural Engineering Laboratory Report No. 66-24, College of Engineering, University of California. Berkeley, Sept., 1966.

3. Housner, G.W., "Behaviour of structures During Earthquakes", Journal of the Engineering Mechanics Division. American Society of Civil Engineers, Vol. 85, No. EM4, Oct., 1959.

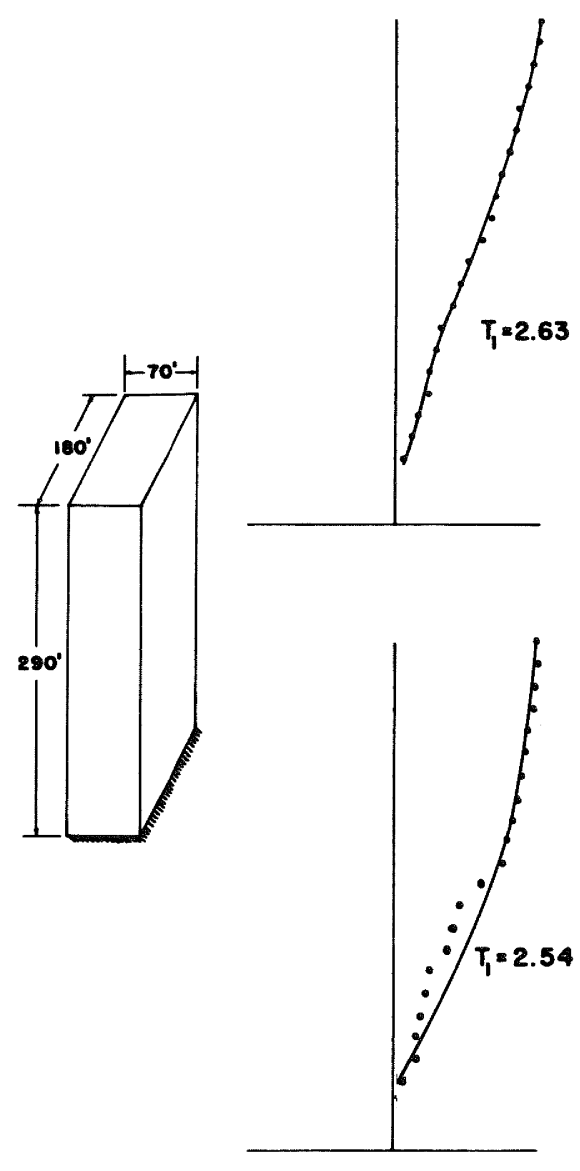

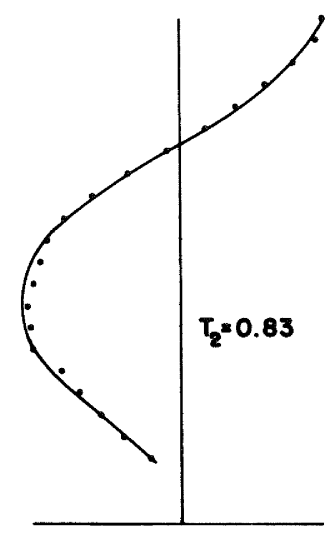

TRANSVERSE MODES
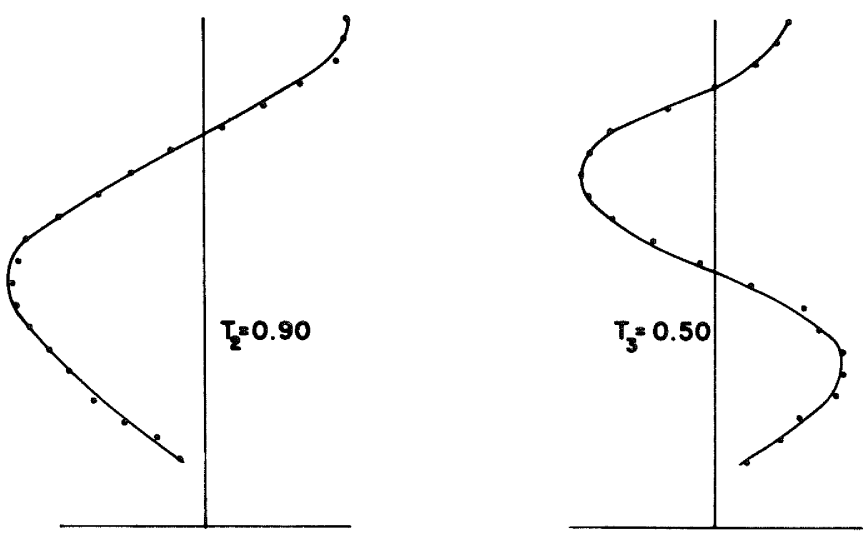

LONGITUDINAL MODES

Fig. 1-Measured translational modes and periods of the San Diego Gas and

Electric Co. Building 

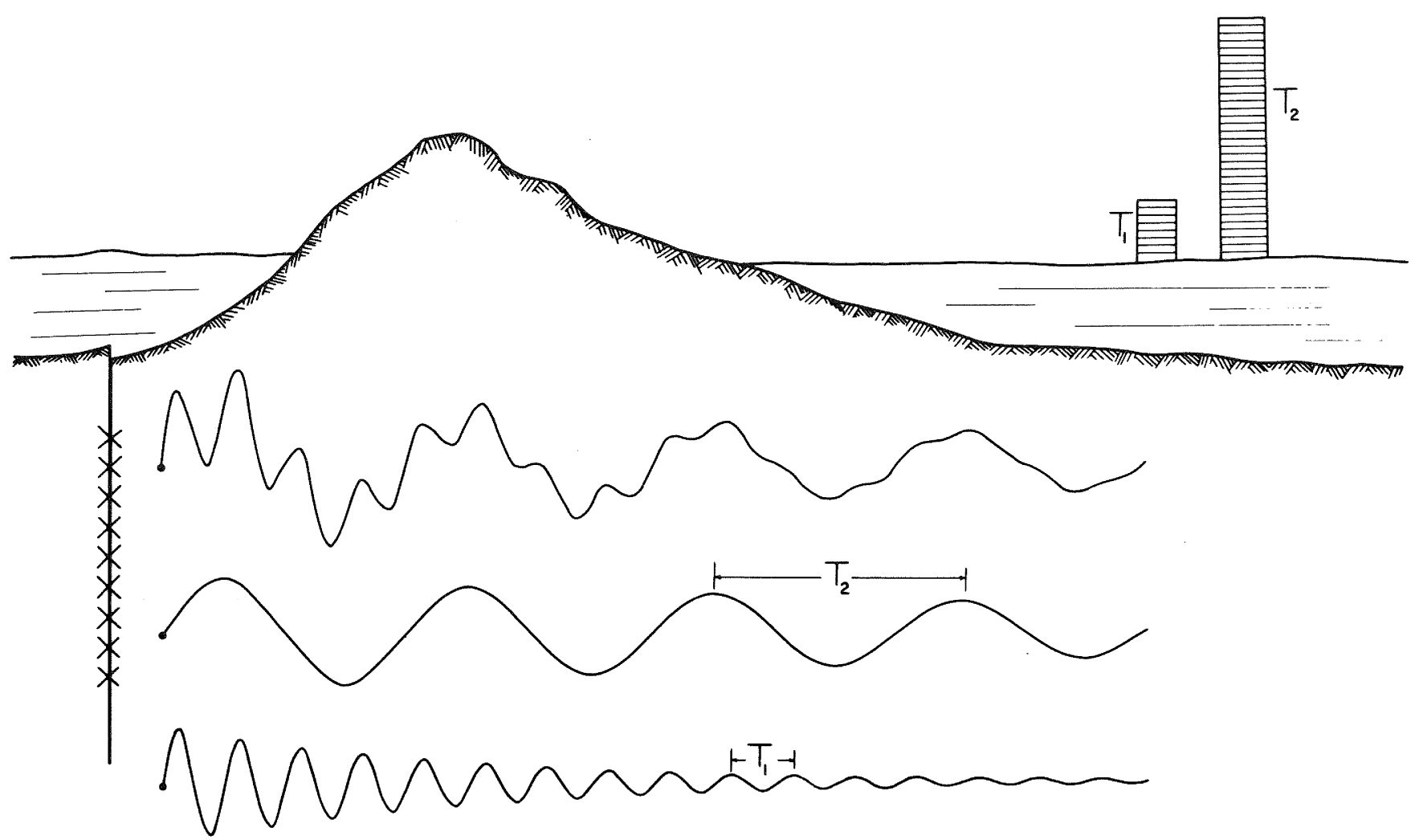

Fig. 2-Schematic diagram illustrating why tall buildings are more sensitive to distant earthquakes than shorter ones (See text)

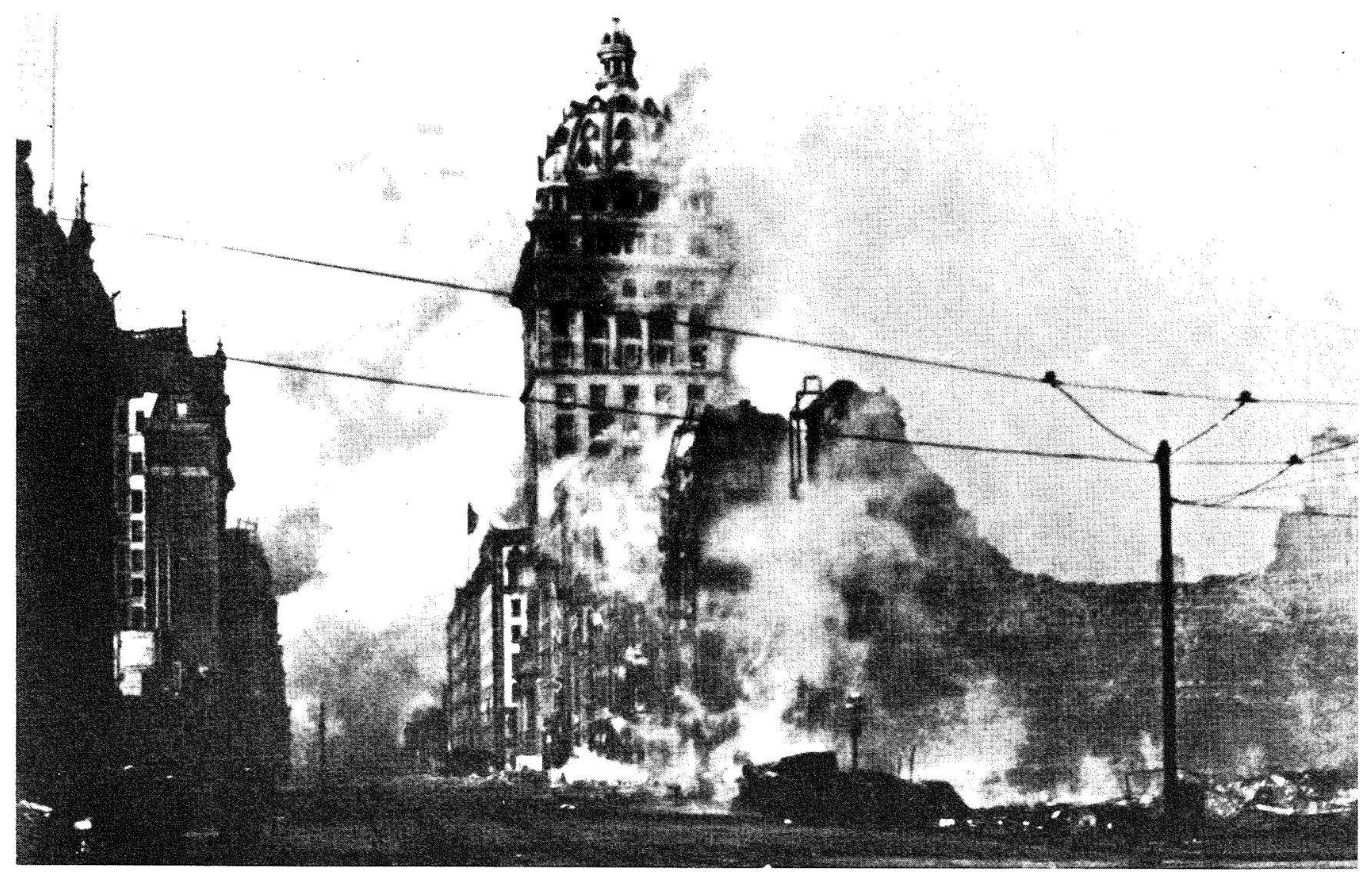

Fig. 3-Market Place, San Francisco and the Call Building after the earthquake of 1906, and during the subsequent fire. 


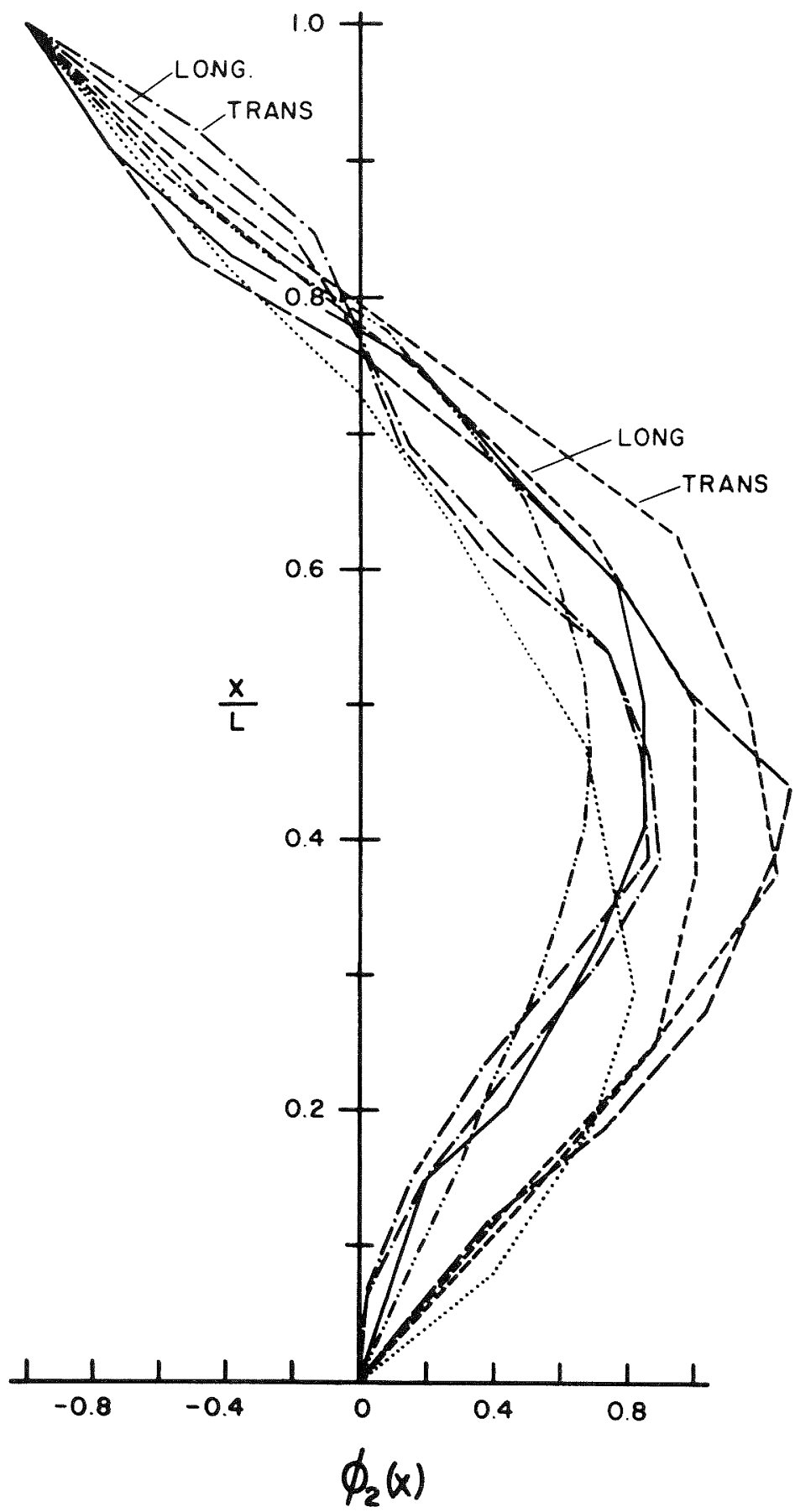

Fig. 4-Second mode shapes of several tall buildings ${ }^{(1)}$ 

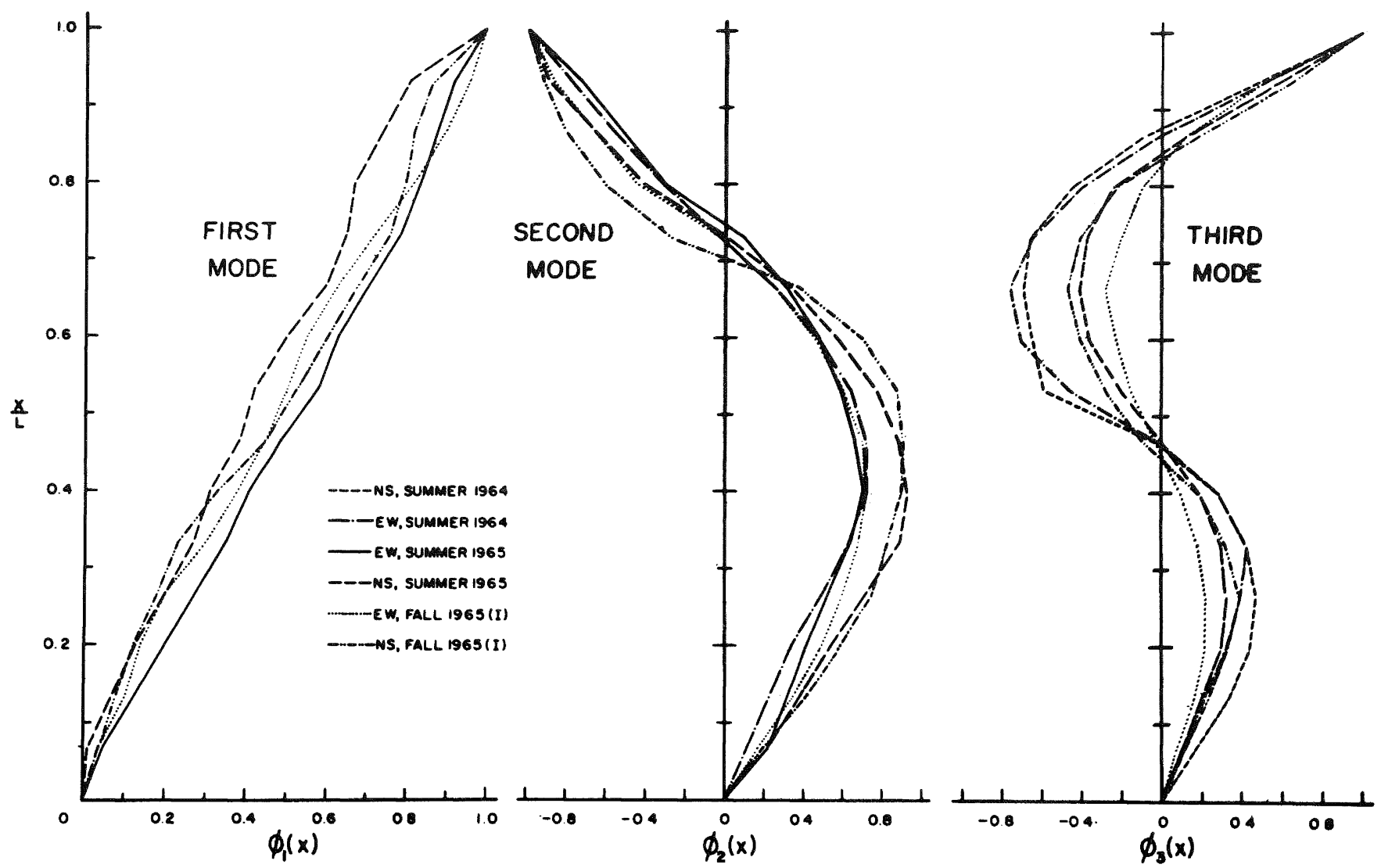

Fig. 5-First three mode shapes of a 15-story building at various stages of construction ${ }^{(2)}$

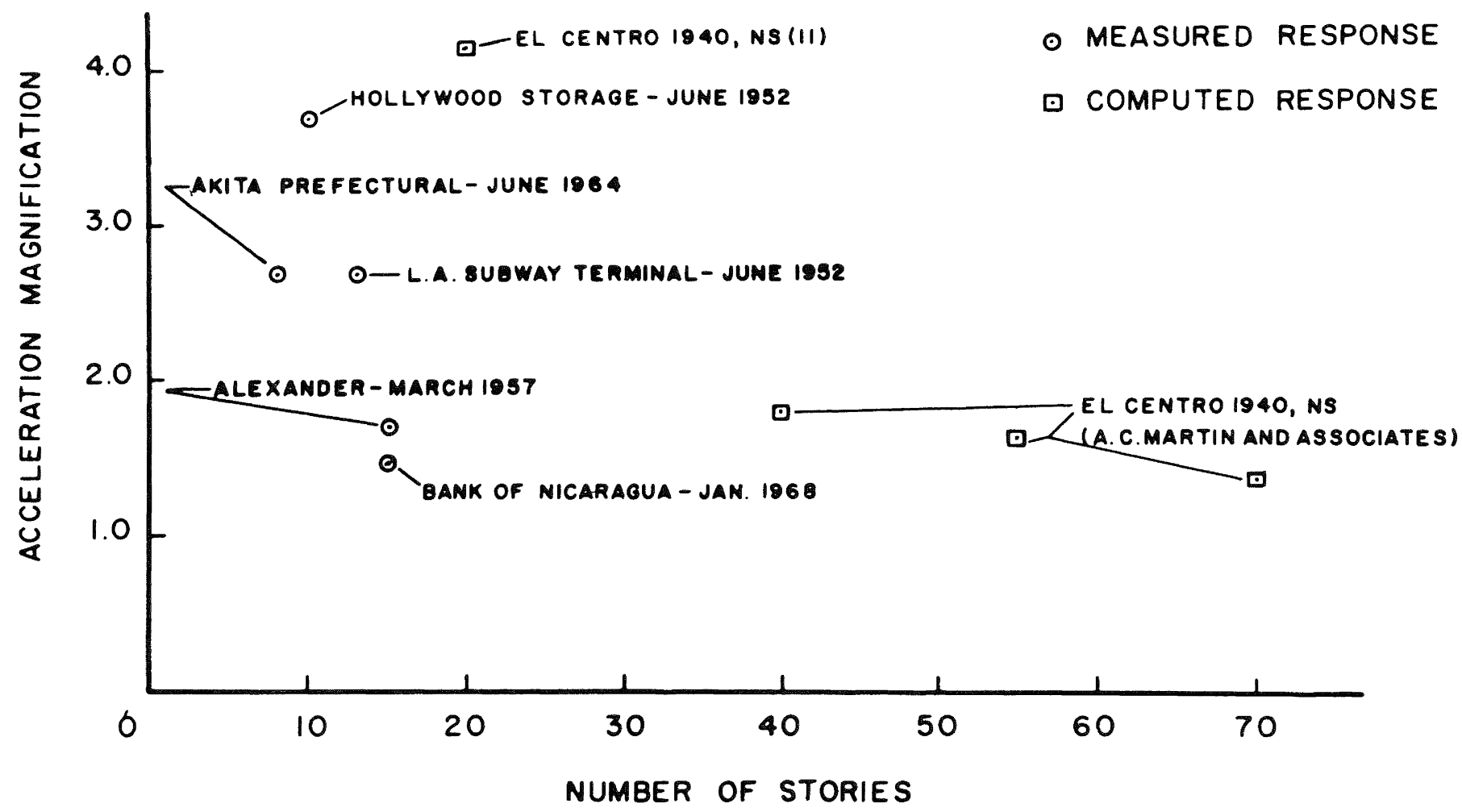

Fig. 6-Ratio of maximum top floor acceleration to base accelerations for the response of tall buildings to strong earthquakes. 
TABLE 1

MEASURED PERIODS OF TALL FRAMED STRUCTURES

\begin{tabular}{|c|c|c|c|c|c|c|c|c|c|c|c|}
\hline \multirow{2}{*}{ Building } & \multirow[b]{2}{*}{ stories } & \multirow[b]{2}{*}{ Type } & \multirow[b]{2}{*}{$\begin{array}{c}\text { Plan } \\
\text { Dimensions } \\
\text { (ft.) }\end{array}$} & \multirow[b]{2}{*}{ Direction } & \multirow[b]{2}{*}{$\mathrm{T}_{1}(\sec )}$. & \multirow[b]{2}{*}{$\mathrm{T}_{1} / \mathrm{N}$} & \multirow[b]{2}{*}{$\mathrm{T}_{1} / \mathrm{T}_{2}$} & & \multirow[b]{2}{*}{$\mathrm{T}_{1} / \mathrm{T}_{6}$} \\
\hline & & & & & & & & $\mathrm{T}_{1} / \mathrm{T}_{3}$ & $\mathrm{~T}_{1} / \mathrm{T}_{4}$ & $\mathrm{~T}_{1} / \mathrm{T}_{5}$ & \\
\hline $\begin{array}{l}\text { Union Bank } \\
\text { Los Angeles }\end{array}$ & 40 & $\begin{array}{l}\text { Steel } \\
\text { Frame }\end{array}$ & $196 \times 98$ & $\begin{array}{l}\text { Long. } \\
\text { Trans. }\end{array}$ & $\begin{array}{l}3.10 \\
3.54\end{array}$ & $\begin{array}{l}0.078 \\
0.088\end{array}$ & $\begin{array}{l}2.90 \\
3.03\end{array}$ & $\begin{array}{l}5.06 \\
5.58\end{array}$ & $\begin{array}{l}7.18 \\
7.96\end{array}$ & $\begin{array}{l}9.25 \\
10.5\end{array}$ & $\begin{array}{l}11.5 \\
13.1\end{array}$ \\
\hline $\begin{array}{l}\text { Canadian Imperial } \\
\text { Bank of Commerce, Montrea }\end{array}$ & $a^{44}$ & $\begin{array}{l}\text { Steel } \\
\text { Frame }\end{array}$ & $140 \times 100$ & $\begin{array}{l}\text { Long. } \\
\text { Trans. }\end{array}$ & $\begin{array}{l}4.65 \\
4.65\end{array}$ & $\begin{array}{l}0.106 \\
0.106\end{array}$ & $\begin{array}{l}2.90 \\
2.72\end{array}$ & $\begin{array}{l}5.06 \\
4.78\end{array}$ & $\begin{array}{l}7.71 \\
7.06\end{array}$ & $\begin{array}{l}9.61 \\
8.93\end{array}$ & $\begin{array}{l}11.9 \\
11.1\end{array}$ \\
\hline $\begin{array}{l}\text { CIL House, } \\
\text { Montreal }\end{array}$ & 34 & $\begin{array}{l}\text { Steel } \\
\text { Frame }\end{array}$ & $168 \times 112$ & $\begin{array}{l}\text { Long. } \\
\text { Trans. }\end{array}$ & $\begin{array}{l}4.46 \\
3.94\end{array}$ & $\begin{array}{l}0.131 \\
0.116\end{array}$ & $\begin{array}{l}3.05 \\
2.84\end{array}$ & $\begin{array}{l}5.58 \\
5.04\end{array}$ & $\begin{array}{l}8.25 \\
7.36\end{array}$ & $\begin{array}{l}11.1 \\
9.85\end{array}$ & 13.6 \\
\hline $\begin{array}{l}\text { Univ. of Cal, } \\
\text { Berkeley, } \\
\text { Medical Center, } \\
\text { East Bldg. (Summer } \\
1964 \text { Tests, frame } \\
\text { and slabs only.) }\end{array}$ & 15 & $\begin{array}{l}\text { Steel } \\
\text { Frame }\end{array}$ & $107 \times 107$ & $\begin{array}{l}E-W \\
N-S\end{array}$ & $\begin{array}{l}1.18 \\
1.18\end{array}$ & $\begin{array}{l}0.078 \\
0.078\end{array}$ & $\begin{array}{l}2.65 \\
2.65\end{array}$ & $\begin{array}{l}4.60 \\
4.60\end{array}$ & $\begin{array}{l}6.54 \\
6.54\end{array}$ & $\begin{array}{l}8.47 \\
8.47\end{array}$ & \\
\hline $\begin{array}{l}\text { Ottawa Post office } \\
\text { Building }\end{array}$ & 10 & $\begin{array}{l}\text { Reinfor } \\
\text { Concret } \\
\text { Frame }\end{array}$ & $\begin{array}{l}\text { ced } \\
266 \times 74\end{array}$ & $\begin{array}{l}\text { Long. } \\
\text { Trans. }\end{array}$ & $\begin{array}{l}0.695 \\
0.592\end{array}$ & $\begin{array}{l}0.070 \\
0.059\end{array}$ & $\begin{array}{l}2.87 \\
2.77\end{array}$ & $\begin{array}{l}4.45 \\
4.16\end{array}$ & $\begin{array}{l}6.30 \\
5.48\end{array}$ & $\begin{array}{l}7.83 \\
7.30\end{array}$ & \\
\hline $\begin{array}{l}\text { Canadian Dept. of } \\
\text { Health and Welfare } \\
\text { Building, Ottawa }\end{array}$ & 18 & $\begin{array}{l}\text { Steel a } \\
\text { concret } \\
\text { Core, s } \\
\text { Columns } \\
\text { Reinfor } \\
\text { Concret } \\
\text { Slabs }\end{array}$ & $\begin{array}{l}\text { ind } \\
140 \times 88 \\
\text { teel } \\
\text { ced } \\
\text { Floor }\end{array}$ & $\begin{array}{l}\text { Long. } \\
\text { Trans. }\end{array}$ & $\begin{array}{l}0.99 \\
1.28\end{array}$ & $\begin{array}{l}0.058 \\
0.075\end{array}$ & $\begin{array}{l}3.75 \\
4.26\end{array}$ & $\begin{array}{l}5.17 \\
6.55\end{array}$ & & & \\
\hline $\begin{array}{l}\text { San Diego Gas and } \\
\text { Electric Co. Bldg, } \\
\text { San Diego. }\end{array}$ & 21 & $\begin{array}{l}\text { Steel } \\
\text { Frame }\end{array}$ & $70 \times 180$ & $\begin{array}{l}\text { Long. } \\
\text { Trans. }\end{array}$ & $\begin{array}{l}2.54 \\
2.63\end{array}$ & $\begin{array}{l}0.121 \\
0.125\end{array}$ & $\begin{array}{l}2.8 \\
3.2\end{array}$ & $\begin{array}{l}5.1 \\
6.0\end{array}$ & $\begin{array}{l}7.6 \\
9.0\end{array}$ & $\begin{array}{l}10.8 \\
11.3\end{array}$ & $\begin{array}{l}13.0 \\
13.0\end{array}$ \\
\hline
\end{tabular}

